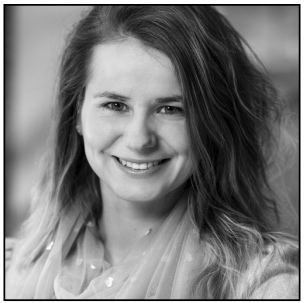

Heili Püümann

\title{
The Legal Meaning of a Detailed Spatial Plan in the Context of the Fundamental Right of Ownership
}

\section{Introduction}

It can be stated that the fundamental right of ownership ${ }^{*_{1}}$ is one of the most important fundamental rights that is stipulated in the Constitution of the Republic of Estonia* (hereinafter CRE). Specifically, it is stipulated in sentence 1 of Section 32 of the CRE that the property of every person is inviolable and is equally protected. The Supreme Court of Estonia (hereinafter SCE) has stated that private ownership has an essential meaning in a society that is based on an open market economy and guarantees the functioning of the open market. ${ }^{*}$ The fundamental right of ownership is protected by several international regulations, which are also applicable in Estonia; for example, it is protected by the Charter of Fundamental Rights of the European Union (Art. 17) ${ }^{*}$.

On the other hand, one can also state that the fundamental right of ownership could be considered one of the most limited fundamental rights provided for by the CRE. Under Estonian law, the fundamental right of ownership is limited through various rights and regulations that are governed by private law - for example, neighbourhood rights (under the Law of Property Act, hereinafter LPA ${ }^{*}$, $§ 143 \mathrm{ff}$ ) - and also via various regulations governed by public law.

The aim behind this article is to determine what the legal meaning of a detailed spatial plan (hereinafter detailed plan) is within the context of the fundamental right of ownership. In principle, a detailed plan could be understood under Estonian law as a restriction (limitation) of the fundamental right of ownership or, alternatively, it could fall under the legal concept of 'designing the fundamental right of ownership' (in line with the explanation in Section 3). The distinction between these legal concepts is essential, because those concepts fall under two separate and distinct schemes of legal regulation in light of the CRE, which differ from each other substantially. If a detailed plan and the conditions laid down in the latter fall under the legal concept of 'restriction of the fundamental right of ownership', the detailed plan and its conditions must be compliant with the requirements foreseen by the CRE for establishment of a restriction to

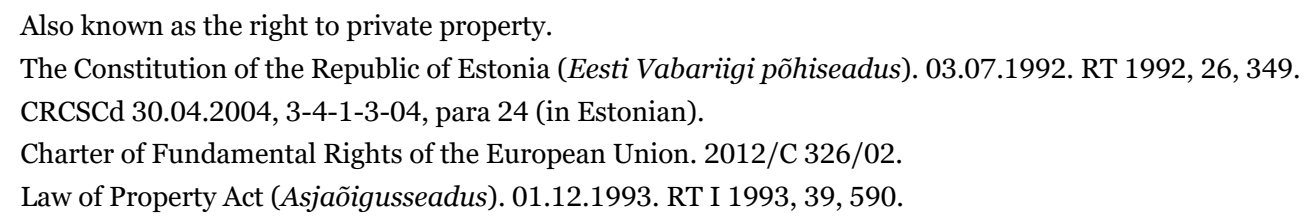


a fundamental right. In this case, the restriction of the fundamental right of ownership compassed must have appropriate legal grounds etc (formal requirements) ${ }^{* 6}$ and it also must be in consistence with the principle of proportionality (material requirements). ${ }^{*}{ }^{*}$ On the other hand, if a detailed plan were to fall under the concept of 'designing the fundamental right of ownership', the above requirements would not apply. For example, in the case of the last scenario mentioned, not every term foreseen in the detailed plan has to have legal grounds set forth by law. In this case, the local government has more freedom and wider discretionary power over the establishment of the detailed plan and its conditions. Notwithstanding the fact that the above-mentioned question has a considerable impact on the establishment of a detailed plan and its conditions, this question is still unresolved in Estonian law.

In the context of the present article, some explanation is important at this juncture. Each of the fundamental rights foreseen by the CRE could be, in principle, classed under three wider categories: i) a fundamental right to freedom (in Estonian, vabaduspõhiõigus), ii) a fundamental right for performance of the state (in Estonian, soorituspõhiõigus), and iii) a fundamental right of equality. ${ }^{*}$ Any one fundamental right, with the fundamental right of ownership (CRE Art. 32) being no exception, might fall under several of these categories. ${ }^{*} 9$ The importance of this distinction is due to the fact that the general category of a fundamental right dictates the logic (control scheme) for how to determine whether the scope of protection for the relevant fundamental right has been restricted. The fundamental right of ownership is indeed one of those fundamental rights that fall under more than one of the above-mentioned categories. ${ }^{* 10}$ Taking into account the legal effect and meaning of the detailed plan (see Section 2) and the fact that the article is written from the immovable property owner's viewpoint, the analyses in this article have been guided from the standpoint of the control scheme, or logic, foreseen for the fundamental right of freedom.

If we are to find a solution to the problem raised above, the following questions must be answered: i) what the legal effect and meaning of a detailed plan is; ii) how to determine and define the legal concept of 'restriction of the fundamental right of ownership' and how to distinguish between the latter legal concept and the other, similar legal concepts; and, finally, iii) what the scope of the protection of the fundamental right of ownership is in light of public construction law and what the legal meaning of a detailed plan is in the context of the fundamental right of ownership.

For finding an answer to those questions, the comparative legal method has been employed. In this research, I compared the Estonian legal system with a legal solution that has been used in Germany. The latter legal system was chosen for comparative analysis for reason of the German legal model's history of serving as a model for Estonian regulation related to the fundamental right of ownership and for the country's regulations related to property rights. In addition, taking the German legal model as a yardstick for comparison is justified by the fact that the SCE has explicitly stated that, for interpretation of those provisions in Estonia that have not yet been interpreted by the SCE, one is allowed to refer to settled court practice from the courts of other European countries - for example, Germany's. ${ }^{*}$

\section{The legal effect and meaning of a detailed plan}

If undertaking to evaluate what the legal meaning of a detailed plan in the context of the fundamental right of ownership actually is, one must proceed from an understanding of the legal concept of a detailed plan. Evaluation of the legal substance and characteristics of a detailed plan requires considering the fact that, in accordance with established SCE practice, a detailed plan is an administrative act ${ }^{* 12}$ (per $\$ 51$ of the

6 CRCSCd 26.11.2007, 3-4-1-18-07, para 35; CRCSCd 01.07.2008, 3-4-1-6-08, para 43; CRCSCd 14.12.2010, 3-4-1-10-10, para 47; CRCSCd 27.02.2015, 3-4-1-54-14, para 47 (in Estonian).

7 CRCSCd 26.03.2009, 3-4-1-16-08, para 28 (in Estonian).

8 M Ernits and others, 'II peatükk (Põhiõigused, vabadused ja kohustused, kommentaar)', Eesti Vabariigi põhiseadus. Kommenteeritud väljaanne. 4., täiend. vlj. ['II Section, Fundamental rights, freedoms and obligations, Executive edition of the Constitution of the Republic of Estonia, 4th edn'] (Tallinn: Juura 2017), para $20<$ https://arhiiv-2017.pohiseadus.ee/index. php?sid=1\&ptid=12> accessed 31 March 2021) (in Estonian).

9 Ibid.

10 Ibid.

11 CCSCd 12.10.2011, 3-2-1-90-11, para 10 (in Estonian).

12 ALCSCd 01.03.2017, 3-3-1-79-16, para 17 (in Estonian). 
Administrative Procedure Act, hereinafter APA). ${ }^{*}{ }^{13}$ The definition of a detailed plan is given in Section 124 of the Planning Act (hereinafter PA) ${ }^{*} 14$, according to whose Subsection 2 said plan must be considered a document aimed at executing the general plan and establishing a complete spatial solution for the area subject to planning. Subsection 2 of the PA's Section 124 also provides for a detailed plan as determining how the planned area is to be used for construction purposes over the coming years. Additionally, it is noted in court practice that, through a detailed plan, the local authority translates the principles for spatial development of the administrative area and specifies the conditions for sustainable and balanced development, which, in turn, constitute the basis for land-use and construction activities. ${ }^{*} 15$ Furthermore, the SCE has stated that a detailed plan could and must be understood as a 'social agreement' governed by public law that addresses how to use a certain area. ${ }^{* 16}$ The substance and legal effect of a detailed plan have been defined in Germany in a similar manner (BauGB, Subsection 5 of §1).

According to statements made in the German legal literature, a detailed plan should be understood as a 'proposal for use of the planning area'. The legal literature of Germany explains that a detailed plan fulfils its legal purpose by determining the planning area and its development principles by way of a 'proposal' as to how a certain area is allowed to be used. ${ }^{*} 17$ One implication is that the owner of the property (or any other interested party), unless provision is made otherwise, does not have an obligation to enforce the detailed plan that is currently valid; however, the provisions set forth in the detailed plan must be followed in the event that any interested party wishes to use the planning area for construction purposes. ${ }^{*}{ }^{18}$ Therefore, a valid detailed plan has quite considerable influence on the nature of the immovable property. For example, the detailed plan determines the property's intended purpose and the associated building rights. It must be emphasised also that a valid detailed plan does not merely 'propose' and foresee how the planning area is allowed to be used; it also precludes the use of the planning area for purposes that are not allowed or foreseen in the detailed plan.

In conclusion, it could be argued that a valid detailed plan in the Estonian context is an administrative act of a kind unto itself. On the one hand, a detailed plan is binding for those who are interested in using the property, when subject to a valid detailed plan. On the other hand, a detailed plan should be understood as a proposal for the use of the planning area too, because nobody has any obligation to enforce the valid detailed plan, except when there are provisions otherwise. Only in cases of the interested party desiring to use the planning area for construction purposes must the provisions set forth in the detailed plan be followed.

\section{The legal concept of 'restriction of the fundamental right of ownership'}

Finding an answer to the question of the legal meaning of a detailed plan in the context of the fundamental right of ownership requires further groundwork: one must understand the legal concept of 'restriction of the fundamental right of ownership'. Achieving this understanding requires one to differentiate clearly between this legal concept and other alternative concepts that are affecting and designing the fundamental right of ownership. As mentioned above, the applicability of the requirements set forth in the CRE in relation to the protection of fundamental rights depends on whether the detailed plan is seen as a restriction of the fundamental right of ownership or not.

It is explained in pertinent commentary that the mechanism of protection for a fundamental right is applicable only in cases wherein the addressee of the fundamental right (the public authority) has unfavourably influenced activities, characteristics, or the status of a thing or a right that fall within the scope of the

13 Administrative Procedure Act (Haldusmenetluse seadus), 01.01.2002, RT I 2001, 58, 354.

14 Planning Act (Planeerimisseadus), 01.07.2015, RT I, 26.02.2015, 3.

15 ALCSCd 27.01.2010, 3-3-1-79-09, para 13 (in Estonian).

16 CCSCd 22.03.2006, 3-2-1-5-06, para 22 (in Estonian).

17 Battis and others, BauGB Baugesetzbuch Kommentar ['Executive comments to Building Code'], 13. Aufl. [edn]. 2016, BauGB $\S 1, \mathrm{Rn} .10-11$ (in German).

18 ALCSCd 05.03.2019, 3-13-385/90, para 12 (in Estonian). 
fundamental right of ownership. ${ }^{*}{ }^{* 19}$ That kind of negative influence can be characterised as a restriction or limitation of the scope of the fundamental right of ownership. ${ }^{{ }^{20}}$ It is explained also that, in determining the scope of the fundamental right of freedom (including the fundamental right of ownership), one must be guided by a wide approach also known as a modern theory of the restriction of the fundamental right. ${ }^{{ }_{21}}$ Under this theory, the scope of a fundamental right of freedom can be deemed to have been restricted in any case in which the sphere of the entitled person's freedom has been influenced in an unfavourable manner. ${ }^{* 2}$ The SCE has stated that every unfavourable affecting of a fundamental right's scope of protection may be classed as restriction of that fundamental right. ${ }^{{ }^{2} 23}$ In Estonian legal literature, it is explained that 'restriction' is a general term covering any prevention, damage, or elimination of the right's sphere of protection for the person entitled to it. ${ }^{*} 4$ Therefore, in short, it can be argued that the legal instrument of the public authority must be seen as restricting the fundamental right of ownership if it has any kind of negative influence on the sphere of freedom connected with said fundamental right.

Writings on Estonian legal theory grant brief acknowledgement to the concept of designing a fundamental right. While the SCE has not in its practice clearly distinguished this legal concept from the concept of 'restriction of the fundamental right of ownership', it must be noted that the SCE's recent practice indirectly recognised the legal concept denoted as 'designing a fundamental right'. ${ }^{25}$ The final report on the legal analysis of the CRE (conducted by the expert commission) states that one must differentiate the concept of regulation restricting a fundamental right from that of regulation designing a fundamental right. ${ }^{{ }^{2} 6}$ In cases of the latter, rather than restrict the legal sphere of the fundamental right, the regulation in question creates the right or articulates prerequisites for exercising it. ${ }^{* 27}$ Any seeming restriction could be considered delimitation or specification of the right. If it is identified that the regulation in question designed the fundamental right, the right has not been restricted thereby, and it is not necessary to justify the regulation in this case. ${ }^{{ }^{2} 8}$ It follows also that the mechanism for protection of a fundamental right does not apply here. ${ }^{{ }^{*} 29}$ This means in practice that a regulation falling under the category 'designing the fundamental right of ownership' need not fully meet the requirements (formal and material) ${ }^{*} 30$ foreseen in the CRE in connection with restrictions to fundamental rights.

Similar legal concepts are addressed in German legal literature. It is explained that not every activity conducted by the state where there is some connection with the fundamental right in question is always

19 M Ernits and others, 'II peatükk (Põhiõigused, vabadused ja kohustused, kommentaar)', Eesti Vabariigi põhiseadus. Kommenteeritud väljaanne. 4., täiend. vlj. ['II Section, Fundamental rights, freedoms and obligations, Executive edition of the Constitution of the Republic of Estonia, 4the edn'] (Tallinn: Juura 2017), para $43<$ https://arhiiv-2017.pohiseadus.ee/index. php?sid=1\&ptid=12> accessed 31 March 2021) (in Estonian).

20 Ibid, para 44.

21 Ibid, para 44.

22 CRCSCd 06.03.2002, 3-4-1-1-02, para 12; CRCSCd 12.06.2002, 3-4-1-6-02, para 9 (in Estonian).

23 SCeb 22.11.2011, 3-3-1-33-11, para 23; CRCSCd 21.01.2014, 3-4-1-17-13, para 26; CRCSCd 15.09.2014, 3-4-1-11-14, para 15 (in Estonian).

24 M Ernits and others, 'II peatükk (Põhiõigused, vabadused ja kohustused, kommentaar), Eesti Vabariigi põhiseadus. Kommenteeritud väljaanne. 4., täiend. vlj. ['II Section, Fundamental rights, freedoms and obligations, Executive edition of the Constitution of the Republic of Estonia, 4th edn'] (Tallinn: Juura 2017), para 44 <https://arhiiv-2017.pohiseadus.ee/index. php?sid=1\&ptid=12> accessed 31 March 2021) (in Estonian).

25 SCebd 20.10.2020, 5-20-3 p 44, para 77.

26 'Eesti Vabariigi põhiseaduse juriidilise ekspertiisi komisjoni lõpparuanne' ['The Final Report of the Legal Analyses of the Constitution of the Republic of Estonia'] (ordered published by the Ministry of Justice). Kommentaarid II peatüki kohta. [Comments to II Section] 12, clause 4.2.2.2 <www.just.ee/sites/www.just.ee/files/elfinder/article_files/pohiseaduse_2._peatukk._pohioigused_vabadused_ja_kohustused.pdf $>$ accessed 31 March 2021.

27 Ibid 12, clause 4.2.2.2.

28 'Eesti Vabariigi põhiseaduse juriidilise ekspertiisi komisjoni lõpparuanne' ['The Final Report of the Legal Analyses of the Constitution of the Republic of Estonia'] (ordered published by the Ministry of Justice). Kommentaarid II peatüki kohta. [Comments to II Section] 12, clause 4.2.2.2 <www.just.ee/sites/www.just.ee/files/elfinder/article_files/pohiseaduse_2._peatukk._pohioigused_vabadused_ja_kohustused.pdf> accessed 31 March 2021.

29 M Ernits and others, 'II peatükk (Põhiõigused, vabadused ja kohustused, kommentaar)', Eesti Vabariigi põhiseadus. Kommenteeritud väljaanne. 4., täiend. vlj. ['II Section, Fundamental rights, freedoms and obligations, Executive edition of the Constitution of the Republic of Estonia, 4th edn'] (Tallinn: Juura 2017), para 43 <https://arhiiv-2017.pohiseadus.ee/index. php?sid=1\&ptid=12> accessed 31 March 2021) (in Estonian).

30 CRCSCd 26.11.2007, 3-4-1-18-07, para 35; 01.07.2008, 3-4-1-6-08, para 43; 14.12.2010, 3-4-1-10-10, para 47; 27.02.2015, 3-4-1-54-14, para 47, CRCSCd 26.03.2009, 3-4-1-16-08, para 28 (in Estonian). 
qualified as 'restriction of a fundamental right' (Beeinträchtigung). ${ }^{*} 31$ The activity of the state may, alternatively, be favourable in light of the interests of the authorised person - for example, the activity of the state may expand authorised persons' freedom for exercise of the fundamental right. ${ }^{*}{ }^{2}$

In cases in which the action carried out by the public authority does not bring about any restrictive effect, one cannot consider activity of this nature to be restriction of the fundamental right. ${ }^{*} 33$ It is explained also that a question arises from the regulation dealing with 'restriction of a fundamental right' as to how one should delimit the concepts of 'concretisation of a fundamental right' (Konkretisierung) and 'designing a fundamental right' (Ausgestaltung) in contrast against the concept of 'limitation of a fundamental right'. ${ }^{34}$ German legal scholars have concluded that it is impossible to define these concepts clearly and that it is reasonable to define them in terms of activities conducted by the public authority that do not fall under 'limitation of a fundamental right' (as a negative concept). ${ }^{*} 35$ When one considers the fact that, on the basis of the legal position referred to above, the protection mechanisms related to fundamental rights shall apply only in cases wherein the fundamental right has been restricted, damaged, or in some other way influenced in a negative manner ${ }^{*}{ }^{36}$, the concept of designing the fundamental right could be understood as an activity of the state that affects the sphere of that fundamental right but at the same time does not limit or exert any other negative influence on the sphere protected by dint of the fundamental right. It could be argued also that the concept of 'designing a fundamental right' should, as a general rule, have a positive influence on the fundamental right (extending the freedom sphere etc).

From the foregoing statements, one could state the following conclusions: The term and legal concept 'affecting a fundamental right' should be understood as covering every activity conducted by the public authority that has any kind of influence on the scope of protection of the fundamental right - the instrument pertains to the fundamental right in some way. The legal term 'affecting a fundamental right' could be considered a general umbrella term encompassing the legal concepts of both 'limitation of a fundamental right' and 'designing a fundamental right'. Estonian legal literature distinguishes between the concept of 'limitation of a fundamental right', which should be understood as referring to an activity conducted by the public authority that has any kind of negative influence on the scope of protection of the fundamental right $^{*}{ }^{37}$, and the concept of 'designing a fundamental right', which should be understood as a legal instrument that provides the prerequisites for enforcement of the fundamental right. Also, a legal instrument could fall under the 'designing a fundamental right' category only if it does not restrain execution of the fundamental right. It could be argued that the key question for distinguishing between the above-mentioned legal concepts is whether the legal instrument has any kind of negative influence on the fundamental right or not. The protection mechanism in place for fundamental rights is applicable only in cases in which the legal instrument falls under the 'restriction of a fundamental right' concept. ${ }^{*} 38$

\footnotetext{
31 M Sachs, Verfassungsrecht II. Grundrechte. 3. Auflage (Heidelberg 2017) 128ff (in German).

32 Ibid 128.

33 Ibid 128.

34 Ibid 129.

35 Ibid 129.

36 Ibid 128.

37 CRCSCd 22.11.2011, 3-3-1-33-11, para 23; CRCSCd 21.01.2014, 3-4-1-17-13, para 26; CRCSCd 15.09.2014, 3-4-1-11-14, para 15.

38 M Ernits and others, 'II peatükk (Põhiõigused, vabadused ja kohustused, kommentaar), Eesti Vabariigi põhiseadus. Kommenteeritud väljaanne. 4., täiend. vlj. ['II Section, Fundamental rights, freedoms and obligations, Executive edition of the Constitution of the Republic of Estonia, 4th edn'] (Tallinn: Juura 2017), para 43 <https://arhiiv-2017.pohiseadus.ee/index. php?sid=1\&ptid=12> accessed 31 March 2021) (in Estonian).
} 


\section{The scope of protection of the fundamental right of ownership in light of public construction law and the meaning of a detailed plan in this context}

This section is devoted to solutions for two key legal issues. Firstly, what is the scope of protection of the fundamental right of ownership in light of public construction law? Secondly, what legal meaning does a detailed plan have in the latter context when one considers the conclusions presented in sections 2 and 3 ? Examining the scope of the protection afforded to the fundamental right of ownership in light of public construction law, one finds explanation that the purpose of the fundamental right of ownership is to ensure the sphere of freedom for the beneficiary of the rights in the area of property rights (and that of matrimonial rights that are similar to property rights) and thereby enable the beneficiary to shape his own life at his own risk. ${ }^{*} 9$ The SCE has explained that the protection of the fundamental right of ownership covers movable and immovable property, as well as monetarily appraisable rights and claims. ${ }^{*}{ }^{40} \mathrm{Also}$, it is explained that proprietary rights such as those to things, money, and monetarily appraisable rights and claims are likewise protected as 'ownership' under Section 32 of the CRE. ${ }^{*}{ }^{4}$

The owner's right to use the owner's immovable for construction purposes falls within the sphere of protection of the fundamental right of ownership. In other words, the scope of protection of this fundamental right encompasses the concept we call 'freedom of construction" ${ }^{\text {, } 42}$. Important provisions that shape the content, meaning, and character of the fundamental right of ownership are found in Section 32 of the CRE and Section 68 of the LPA. Under these provisions, the owner has the right to possess, use, and dispose of a thing and to demand prevention of the violation of these rights and elimination of the consequences of violation by all other persons. Because use of a property for constructional purposes is just one of many possible ways of utilising a property, one could argue that the concept of 'freedom of construction' falls under the sphere of protection of the fundamental right of ownership as well.

Although the principles presented above have been in force already since the 1990 s and therefore one could also argue that the concept of 'freedom of construction' too has been applied since then, there is no sign of the Estonian legislator having acknowledged the concept of 'freedom of construction' until 2015. With the explanatory memorandum on the new Building Code (hereinafter BC), ${ }^{*} 43$ the legislator explained that 'it is clear that within the meaning of the CRE, any establishment of rules for the use of immovable property - including for using the immovable property - constitutes a restriction. Following the example of other countries, one can also talk about a so-called concept of freedom of construction, which could be considered a part of the fundamental right of ownership. ${ }^{*}{ }^{4}$ The legislator has defined the concept of freedom of construction as follows: '[U]nder the concept of construction freedom, one must understand the right of the owner of an immovable to improve its immovable and use its property for construction purposes within the frames of valid legislation. ${ }^{*} 45$

In the German legal literature, it has been explained that the concept of freedom of construction is a traditional element protected under the fundamental right of ownership. ${ }^{*}{ }^{46}$ The fundamental right of ownership (see Grundgesetz für die Bundesrepublik Deutschland, ${ }^{*} 47$ hereafter GG, Art. 14) assures and guarantees for the owner of the property the right to use the property for construction purposes within the

39 M Ernits and others, 'Paragrahv 32 (Omandipõhiõigus) kommentaar', Eesti Vabariigi põhiseadus. Kommenteeritud väljaanne. 4., täiend. vlj.' ['Paragraph 32, Fundamental right of ownership, Executive edition of the Constitution of the Republic of Estonia, 4th edn'] (Tallinn: Juura 2017), para 1 <https://arhiiv-2017.pohiseadus.ee/index.php?sid=1\&ptid=37\&p=32> accessed 1 April 2021) (in Estonian).

40 CCSCd 17.06.2004, 3-2-1-143-03, para 18; CRCSCd 26.06.2014, 3-4-1-1-14, para 88.

41 SCeb 31.03.2011, 3-3-1-69-09, para 56.

42 Also named as construction freedom.

43 Building Code (Ehitusseadustik) 01.07.2015, RT I, 05.03.2015, 1.

44 Seletuskiri ehitusseadustiku juurde. SE 555. ['Explanatory memorandum to Building Code' SE 555] 3-4 <https://www. riigikogu.ee/tegevus/eelnoud/eelnou/9e8a422c-beb8-476c-897c-f9b761fb9b92/Ehitusseadustik> accessed 06 January 2020) (in Estonian).

45 Ibid.

46 Maunz and others, Grundgesetz-Kommentar, ['Executive edition to constitution'] GG, art 14 Rn. 164, 165 (in German).

47 Grundgesetz für die Bundesrepublik Deutschland. 23.05.1949. 
frames of valid legislation. ${ }^{*} 48$ It is explained that, in addition to many other rights that are protected under the sphere of the fundamental right of ownership, the concept of freedom of construction too is covered. ${ }^{*} 49$ It is also clarified that the right of using the immovable for construction purposes is not 'something' (some right) that is granted to the owner of the property by the authorities from 'outside'. ${ }^{*}{ }^{\circ}$ Under the concept of freedom of construction, the right to use one's property for construction purposes is not a right given by the authorities but part of the fundamental right of ownership. ${ }^{* 1}$ The right to use one's immovable for construction purposes is one of the essential parts of the immovable property and all norms that restrict the latter - in particular, the norms related to planning and construction law - constitute restrictions on the free use of immovable property. ${ }^{*}{ }^{2}$

In conclusion, on the basis of the legal positions addressed above, it can be stated that the concept of freedom of construction is an essential element of ownership protected under the CRE also. The legal concept of freedom of construction should be understood as the right of the immovable's owner to use said immovable property for construction purposes within the frames of the valid legislation. ${ }^{*} 3$

Now we can turn to the legal meaning of a detailed plan in the context of the fundamental right of ownership. The legal positions published through Estonian court practice and in the legal literature are unclear and may even be controversial in this regard. The Estonian legislator has stated in the explanatory memorandum on the BA that all of the regulations pertaining to building and planning law should be seen as restriction to the fundamental right of ownership. ${ }^{*} 4$ It is explained also that, because freedom of construction as an element of the fundamental right of ownership is protected under the CRE, one must note that every change in any legal status of a certain property in the sense of building or planning law is subject to constitutional review (in pursuit of legitimate expectations and legal certainty). ${ }^{*} 5$ The legal literature clarifies, furthermore, that the most commonly imposed restrictions on the use of immovable property, which have been established by way of an administrative act, are the restrictions that have been established by plans of various sorts. ${ }^{*} 56$ It could be argued that the opposite position has been presented by the SCE, in that the SCE concluded that a detailed plan cannot be considered to be a restriction provided by the law ${ }^{*} 57$ (it must be emphasised that this position was expressed in a very particular context). On the other hand, though, the SCE has found in its practice that restriction of the fundamental right of ownership was present when local authorities refused to initiate detailed-plan proceedings. ${ }^{*} 8$

Proceeding from the conclusion presented in the argumentation above, one must reason that a valid detailed plan and, moreover, the terms set forth in that detailed plan, must be considered as restricting the concept of freedom of construction - especially when one accounts for the fact that, in accordance with the concept of freedom of construction, the property-owner has, in principle, an unlimited right to use that property for construction purposes (see the first part of $\$ 32$ of the CRE and the first two items in Subsection 1 of the LPA's §68). A detailed plan and the terms specified therein for the use of the property do restrict the concept of freedom of construction. One can readily argue that a valid detailed plan eliminates the possibility of the property-owner putting the property to use for any purpose other than or in any way other than that provided for by the valid detailed plan. One could argue also that a valid detailed plan precludes the use of the property for possible purposes that are not expressly allowed or foreseen by the detailed plan. For example, in the event that it is allowed per the valid detailed plan for the property-owner to use the property as residential land, it is not possible for the owner to use the plot as industrial land. Also, if

\footnotetext{
Maunz and others, Grundgesetz-Kommentar, ['Executive edition to constitution'] GG, art 14 Rn. 164, 165 (in German).

Ibid.

50 Ibid.

51 Battis and others, BauGB Kommentar ['Executive edition to Building Code'], 14. Aufl. [edn]. 2019, BauGB § 1, Rn 10-11 (in German).

52 Maunz and others, Grundgesetz-Kommentar, ['Executive edition to constitution'] GG, art 14 Rn. 164, 165 (in German).

53 Seletuskiri ehitusseadustiku juurde SE 555. ['Explanatory memorandum to Building Code'] 3-4 <https://www.riigikogu. ee/tegevus/eelnoud/eelnou/9e8a422c-beb8-476c-897c-f9b761fb9b92/Ehitusseadustik> accessed 6 January 2020) (in Estonian).

54 Ibid.

55 Ibid.

56 U Volens, "Ses hulluses on siiski järjekindlust" ehk kinnisomandi kitsenduste süsteemi otsimas' ["However, there is consistency in this madness of 'looking for a system of property restrictions'] (2013) VII Juridica 491 (in Estonian).

57 CCSCd 3-2-1-5-06, para 22; CCSCd 3-2-1-48-10, para 28.

58 SCebd, 03.12.2007, 3-3-1-41-06, para 20.
} 
the detailed plan provides that the intended purpose of the property is 'urban park', then the owner's right to put the property to construction-related uses is almost entirely precluded. It must be concluded, then, that the terms foreseen in a detailed plan could be seen as not restricting the fundamental right of ownership only when the terms do not have any negative (restrictive) impact on the further contractual use of the property (i.e. when the terms of the detailed plan just expand the sphere of freedom of the property-owner). Therefore, one could argue that the detailed plan and its terms must be generally understood as restrictions of the fundamental right of ownership.

Because of the inconsistency of the legal positions presented in the legal literature and in Estonian court practice, it would be advisable to evaluate whether the conclusions drawn are supported by German legal literature. In the German legal literature, jurists explain that a detailed plan must be regarded as a restriction of the fundamental right of ownership that does not bring with it an obligation to remedy the damage caused by the establishment of the detailed plan. ${ }^{*} 9$ It is explained also that, since cases in which a detailed plan exists leave the owner of the property room to exercise freedom of construction only within the frames laid down by the detailed plan, the freedom of construction is indeed restricted by the detailed plan. ${ }^{*} 60$ Therefore, the conclusion drawn above is supported by the legal positions presented in German legal literature.

In conclusion, it can be stated more generally in light of the discussion above that a detailed plan and, moreover, the terms set forth in the detailed plan should be considered to constitute restriction of the concept of freedom of construction.

\section{Conclusions}

At the beginning of the article, three questions were raised: i) what is the legal effect and meaning of a detailed plan, ii) how can one determine and define the legal concept of 'restriction of the fundamental right of ownership' and distinguish that concept from similar legal concepts, and iii) what is the scope of the protection of the fundamental right of ownership in light of public construction law - and what is the legal meaning of a detailed plan in the context of the fundamental right of ownership?

We can conclude, firstly, that a valid detailed plan is an administrative act of its own kind. On the one hand, a detailed plan is binding for those persons interested in using the property that is subject to said detailed plan (if valid). At the same time, a detailed plan should be understood as a 'proposal for use of the planning area' because nobody has an obligation to enforce the valid detailed plan (unless provision is made otherwise); it is only when the interested party wants to use the area under planning for construction purposes that the provisions made in the detailed plan must be honoured. Nonetheless, it is clear that a valid detailed plan has a remarkable influence on one's opportunities to use the property in question for construction purposes.

Secondly, one can conclude that the term and legal concept 'affecting a fundamental right' should be understood to cover every activity conducted by the public authority that has any kind of influence on the scope of protection of the relevant fundamental right. The legal concept of 'affecting a fundamental right' could be considered an umbrella one encompassing the legal concepts 'limitation of a fundamental right' and 'designing a fundamental right' as subcategories. Estonian legal literature distinguishes between the concept of 'limitation of a fundamental right', which should be understood as referring to an activity conducted by the state that has a negative influence - of any kind - on the scope of protection of the relevant fundamental right, and the concept of 'designing a fundamental right'. The latter term should be viewed as denoting a legal instrument that forms the prerequisites for enforcement of the fundamental right. Also, a legal instrument may be categorised under a third concept, 'transforming a fundamental right', but only if it does not constrain the exercise of the fundamental right. One could well argue that the key question for distinguishing among the above-mentioned elements is whether or not the legal instrument has any kind of negative influence on the fundamental right.

59 Battis and others, BauGB Baugesetzbuch Kommentar ['Executive comments to Building Code'], 14. Aufl. [edn]. 2019, BauGB $\S 1$, Rn. 123,124 (in German).

60 Battis and others, BauGB Baugesetzbuch Kommentar ['Executive comments to Building Code'], 14. Aufl. [edn]. 2019, BauGB $\S 1,1$ Rn. 7-8 (in German). 
Our answers to the main question for this article permit us to state the following. The legal concept of freedom of construction should be understood as referring to an immovable-owner's right to use the immovable property for construction purposes freely within the frames of the valid legislation. ${ }^{*} 61$ The legal base for the concept of freedom of construction is Section 32 of the CRE, which is aimed at ensuring the sphere of freedom for the beneficiary of those rights within the domain of property rights and matrimonial right similar to property rights, thereby enabling the beneficiary to shape his own life at his own risk. ${ }^{* 62} \mathrm{We}$ have concluded also that a legal instrument falls under the concept of 'designing a fundamental right' only when it does not restrict the exercise of the fundamental right. A detailed plan eliminates the propertyowner's opportunity to use the property for any purpose other than that articulated by the detailed plan, and, again, one could argue that a valid detailed plan precludes the use of the property for purposes not specified in the detailed plan. From these conclusions, one can justifiably conclude that a detailed plan and the specific terms set forth therein should be considered to constitute restrictions to the concept of freedom of construction and to the fundamental right of ownership. In fact, the terms specified in the detailed plan must be seen as restrictive to the fundamental right of ownership unless the terms established terms therein have no negative influence of any sort on the usage of the property.

What does that mean, and why is this conclusion so important? Because a detailed plan and the terms provided in it must be regarded in general as restricting the scope of the fundamental right of ownership, an administrative organ must follow the requirements set forth by the CRE in relation to establishment of restrictions to the fundamental right of ownership. Hence, the terms foreseen in a detailed plan must have appropriate legal grounds, etc. (formal requirements) ${ }^{*} 63$, and the established terms must also be in keeping with the principle of proportionality (material requirements). ${ }^{*} 64$ The principle of proportionality means that the terms foreseen in a detailed plan must have a legitimate purpose (there must be a necessity in light of public interests). It means also that the terms specified in a detailed plan must be suitable, appropriate, and moderate in view of that legitimate purposes for the terms of the detailed plan.

61 Seletuskiri ehitusseadustiku juurde. SE 555. ['Explanatory memorandum to Building Code’] 3-4 <https://www.riigikogu.ee/ tegevus/eelnoud/eelnou/9e8a422c-beb8-476c-897c-f9b761fb9b92/Ehitusseadustik> accessed 6 January 2020 (in Estonian); Maunz and others, GG, art 14 Rn. 164, 165.

62 M Ernits and others, 'Paragrahv 32 (Omandipõhiõigus) kommentaar' in Eesti Vabariigi põhiseadus. Kommenteeritud väljaanne. 4., täiend. vlj. ['Paragraph 32, Fundamental right of ownership, Executive edition of the Constitution of the Republic of Estonia, 4th edn'] (Tallinn: Juura 2017), para 1 <https://arhiiv-2017.pohiseadus.ee/index.php?sid=1\&ptid=37\&p=32> accessed 1 April 2021) (in Estonian).

63 CRCSCd 26.11.2007, 3-4-1-18-07, para 35; 01.07.2008, 3-4-1-6-08, para 43; 14.12.2010, 3-4-1-10-10, para 47; 27.02.2015, 3-4-1-54-14, para 47 (in Estonian).

64 CRCSCd 26.03.2009, 3-4-1-16-08, para 28 (in Estonian) 